\title{
ナミハダニの平坦面に対する付着力と付着機構*
}

\author{
水 谷 勝 己*1, 江 頭 快*2 \\ 東 海正 ${ }^{* 3}$, 大 串 潤*4
}

\section{Adhesive Force of a Spider Mite, Tetranychus urticae, to a Flat Smooth Surface}

\author{
Katsumi MIZUTANI*5, Kai EGASHIRA, \\ Tadashi TOUKAI and Jun OGUSHI
}

${ }^{* 5}$ Department of mechanical engineering and biomimetics, Kinki University,
930 Nishimitani, Uchita-cho, Naga-gun, Wakayama, 649-6493 Japan

\begin{abstract}
Adhesion of a spider mite to a surface of a flat smooth plate is investigated as a model for micromachine parts to adhere to and move on such surfaces. Adhesive force is measured using a setup with a cantilever at the end of which the plate is mounted. The measurement is carried out under various conditions in which plate material, surface roughness of a plate and environmental humidity are varied. The mechanism of adhesion of leg tips of a spider mite to a plate surface is also discussed. Of the forces acting between them, force from dispersion interactions is the most dominant because (1) there is high correlation between adhesive force and the component of dispersion force of surface energy in the surfaces tested: adhesive force of $8.7 \mu \mathrm{N}$ for glass, $9.7 \mu \mathrm{N}$ for mica, $9.9 \mu \mathrm{N}$ for silicon and $12.1 \mu \mathrm{N}$ for gold; and (2) high humidity and high surface roughness decrease adhesive force. For strong adhesion based on work of adhesion, spider mites have tenent hairs with a bell-shaped tip.
\end{abstract}

Key Words: Micromachine, Tribology, Spider Mite, Tenent Hair, Adhesive Force, Work of Adhesion, Surface Energy, Dispersion Interaction

\section{1.}

機械は外部に力仕事を行うとき反力を受ける．機 械の位置を固定してその作業を行わせるためには, 反 力に耐え得る地表面一の固定が必要となるが，平坦面 のように把持するものがないところでは強い固定は困 難である. 特に, 自重による摩擦力が期待出来ないマ イクロマシンでは, どのような機構を用いて固定する かは重要な問題である. 報告されているものとして, 細管内走行マイクロマシンにおける壁面への張り出し を対称位置で行う機構( )，細管外壁走行における数台

* 原稿受付 2004 年 9 月 8 日.

*1 正員, 近畿大学生物理工学部(画649-6493 和歌山県那賀郡 打田町西三谷 930).

*2 正員, 京都工芸繊維大学工芸学部 (昰606-8585 京都市左京 区松ヶ崎御所海道町).

${ }^{* 3}$ 近畿大学大学院生物理工学研究科[現：(株)ナガセインテグ レックス].

*4 近畿大学大学院生物理工学研究科.

E-mail : mizutani@waka.kindai.ac.jp
のマシンを外壁に沿って輪状に連結する機轈めなどが ある. しかし, このように閉じた形が確保できるもの に比べ, 広い平坦面上にある場合には固定のための良 い方法は簡単には見当たらない.

一方，生物では，ヤモリに見られるごとく，どの ような向きの壁面でも落下することなく移動できる小 動物が少なからず存在する. そのため, これらに着目 して平坦面への付着による固定とその離脱を検討する こととした. 対象生物をナミハダニ（体長が $0.5 \mathrm{~mm}$ 程度, 体重が $0.02 \mathrm{mg}$ 程度) とし予備調查を行ったと ころ, ガラス面上で, 走行速度は 1 秒間に体長の数倍, 付着力は体重の数十倍であった . 物体の寸法が小さ くなると支配的な力が体積力から表面力に変わるが, 移動と付着の相反する機能を発揮しているこのダニに あっては双方の力に巧く適応しているものと考えられ る.

そこで, 本研究では, ナミハダニの平坦面に対す る付着力を平坦面の材質や表面粗さ, 測定時の湿度を 変えて詳細に調査する. また，そのもとになる付着の 
機構を脚先の構造, 脚の動作, 付着モデルなどから検 討する.

\section{2.ナミハタン}

ダニは動物分類学上, 節足動物門, 鋏角垔門, クモ 形網，ダニ目に属し，羽が無く四対の脚を持ち，昆虫 とは区別される(4。ここで取り上げたナミハダニは図 1 のような形態をした植物寄生性のダニである. イン ゲン豆を用いて多数の飼育をしたところ，通常は豆葉 の裹に生息し，口針により細胞組織液を吸引するが， それがなくなると他の葉へ，さらには他の幹の葉，他 の木の葉へと活発に移動するものであった. ナミハダ 二の体長は図 1 のごとく上方から見たときの最大長と して, 体重は電子天秤で測定可能となる多数のダニの 重さから求めた. 平均値として体長 $0.5 \mathrm{~mm}$, 体重 $0.023 \mathrm{mg}$ を得た。

\section{3. 付着力の渭定}

3.1 溂定方法 付着力の測定のために構成した 装置の概略を図 2 に示寸．実体影微鏡下に置いて使用 し，付着力によるカンチレバーのたわみを計測する。 そのため, やわらかいカンチレバー先端のステージ上 にガラス等の平坦面を固定し，ステージの下には隙間 を隔てて微小変位計（マイクロセンス 3401-HR-02, 日 本エー・ディー・イー社）を設置している．測定の操 作は, ガラス棒の極細の先端とダニの背を接着する, ガラス棒を操作してステージ上にダニを置く，ダニ自 身で平坦面に付着するよう数秒間保持した後ガラス棒 を引き上げる，である．この操作過程で計測されたス テージの変位波形は図 3 のごとくである. ダニを載せ ることによって一旦下がったステージが引き上げられ， 最高を示した後に離脱して堿哀振動した様子が推察出 来るものとなっている. 従って, 変位波形の最上点と 减衰振動振幅の中央線との変位差から最大変位を, 最 大変位にカンチレバーのバネ定数を乗じて付着力を求 めた。ここで用いたカンチレバーのバネ定数は $0.98 \pm 0.12 \mathrm{~N} / \mathrm{m}$ である。

平坦面として, 哪琒酸ガラス（カバーガラス用: 以 下，ガラスと略記），シリコンウエハー（（100） 面 : 以下，シリコンと略記），雲母（蒸着基板用）, ガラス上に金のスパッタリング膜を施したもの（膜厚 約 $100 \mathrm{~nm}$ : 以下，金スパッタ膜と略記）を用いた. それぞれの面は，目視では非常に平滑で，原子間力顕 微鏡（Dimension3100, DI 社）で様々な個所を粗さ 測定 $(1 \mu \mathrm{m} \times 1 \mu \mathrm{m}$ の測定範囲 $)$ したところ中心線平 均粗さRaは表 1 のごとくであった.

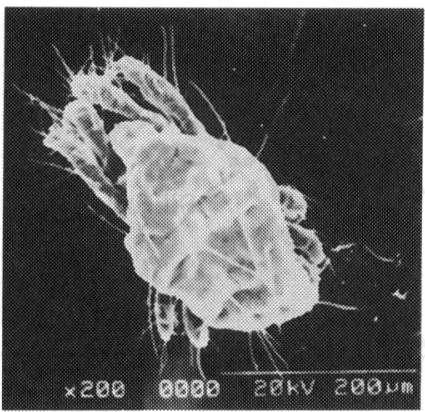

Fig. 1 Spider mite (Tetranychus urticae).

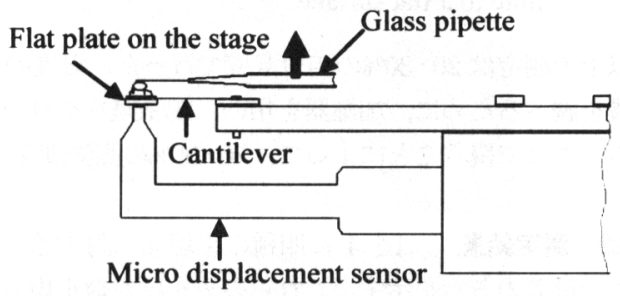

Fig. 2 Setup for measuring adhesive force of a spider mite to a surface of a plate.

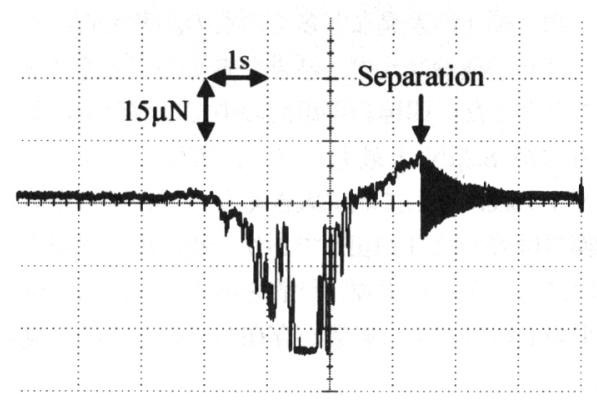

Fig. 3 Time chart of adhesive force.

Table 1 Surface roughnesses of materials Ra used for measuring adhesive force.

\begin{tabular}{c|cccc}
\hline & Glass & Mica & Silicon & $\begin{array}{c}\text { Gold } \\
\text { film }\end{array}$ \\
\hline $\begin{array}{c}\text { Mean surface } \\
\text { roughness nm } \\
\pm \text { S.D. }\end{array}$ & $\begin{array}{c}1.08 \\
\pm 0.30\end{array}$ & $\begin{array}{c}0.36 \\
\pm 0.19\end{array}$ & $\begin{array}{c}0.24 \\
\pm 0.10\end{array}$ & $\begin{array}{c}14.03 \\
\pm 2.26\end{array}$ \\
\hline $\begin{array}{c}\text { Number of } \\
\text { measurements }\end{array}$ & 21 & 26 & 26 & 31 \\
\hline
\end{tabular}

ガラスについては粒度の異なる砥粒（\#800, \#1500, \#4000）を用いたラッピングにより表面を粗くしたもの も用いた. 表面粗さ測定器 (SE-3400, 小阪研究所) に よる表面粗さは $0.006 \mu \mathrm{mRa}$ (平滑面)， $0.039 \mu \mathrm{mRa}$

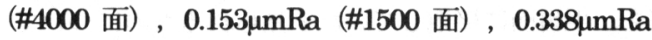
(\#800面)であった. 


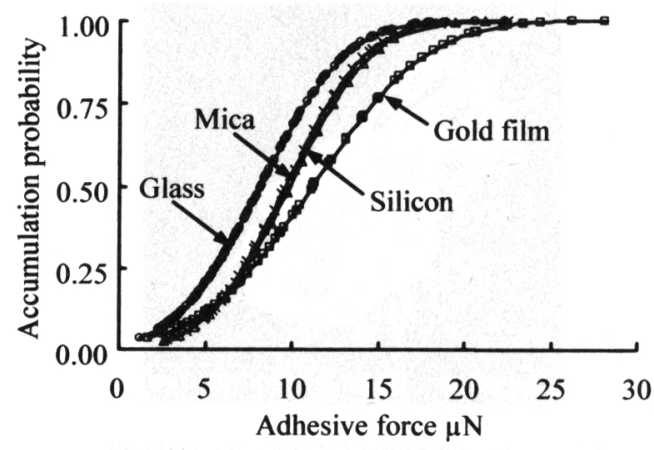

Fig. 4 Distributions of adhesive forces of a spider mite to a flat surface.

以上の測定は $20-30 \%$ の相対湿度で行った．湿度の 影響を調べるために, 加湿器を用い, 顕微鏡をグロー ブボックスで覆うことによって，70-80\%の高湿度を 得た.

3.2 测定結果図 4 に四種の平坦面に対する八 ダニの付着力分布を示す. これらの分布は対数正規分 布に適合するものであった. 分布の原因として, ダニ の個体差, 付着に関係した脚の数, 接地点の平坦面の 状態, 測定操作の差異など多くのものが考えられるが, ここではその議論はせず，結果を表 2 のごとくにまと めることとした. 四種の平坦面の中ではガラスに対す る付着力が $8.2 \mu \mathrm{N}$ と最も小さく, 雲母, シリコン, 金スパッ夕膜に対して順に大きくなっていく. 金スパ ッ夕膜の付着力は $12.1 \mu \mathrm{N}$ であり, 他に比べて粗さが 大きいにもかかわらず強い付着を示すことから，付着 には平坦面材質による影響が存在しているものと見ら れる.

表 3 にガラスの場合について平坦面を粗くしたとき の付着力を示す. ガラス面をラッピングすることによ り付着力は半分程度に低下する. しかし，ラッピング 面の中では，砥粒の粒度により粗さが相当異なるにも かかわらず付着力はほぼ同じである.

表 4 にガラスの場合について測定時の相対湿度を変 えたときの付着力を示す。ここでは, 再現性の確認の ため(a)高湿度状態, (b)低湿度状態, (c)高湿度状態の 順で測定を行っている. 明らかに, 低湿度に比べて 70-80\%の高湿度の状態では付着力は低下している.

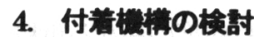

4.1 脚先の構造 ナミハダニの脚は基本的には 基節から始まり跗節に至る六つの節とその先にある粘 毛と爪間体から成る. そのうちの接地に関係する脚先 部を，平坦面に接地していたと見られるものについて 図 5 に SEM 写真で示す．また，一匹のダ二を腹側か
Table 2 Adhesive forces of a spider mite to a flat surface.

\begin{tabular}{c|cccc}
\hline & Glass & Mica & Silicon & $\begin{array}{c}\text { Gold } \\
\text { film }\end{array}$ \\
\hline $\begin{array}{c}\text { Mean adhesive } \\
\text { force } \mu \mathrm{N} \\
\pm \text { S. D. }\end{array}$ & $\begin{array}{c}8.2 \\
\pm 3.8\end{array}$ & $\begin{array}{c}9.7 \\
\pm 3.6\end{array}$ & $\begin{array}{c}9.9 \\
\pm 3.7\end{array}$ & $\begin{array}{c}12.1 \\
\pm 6.8\end{array}$ \\
\hline $\begin{array}{c}\text { Number of } \\
\text { samples }\end{array}$ & 381 & 128 & 59 & 211 \\
\hline
\end{tabular}

Table 3 Adhesive forces of a spider mite to a glass surface unabraded or abraded.

\begin{tabular}{c|cccc}
\hline & Un- & \multicolumn{4}{c}{ Abraded with powders of: } \\
& abraded & $\# 4000$ & $\# 1500$ & $\# 800$ \\
\hline $\begin{array}{c}\text { Mean adhesive } \\
\text { force } \mu \mathrm{N} \\
\pm \text { S.D. }\end{array}$ & $\begin{array}{c}8.7 \\
\pm 3.8\end{array}$ & $\begin{array}{c}3.8 \\
\pm 1.8\end{array}$ & $\begin{array}{c}4.3 \\
\pm 1.4\end{array}$ & $\begin{array}{c}3.9 \\
\pm 1.9\end{array}$ \\
\hline $\begin{array}{c}\text { Number of } \\
\text { samples }\end{array}$ & 30 & 26 & 22 & 25 \\
\hline
\end{tabular}

Table 4 Adhesive forces of a spider mite to a glass surface at different humidities.

\begin{tabular}{c|ccc}
\hline$*$ & $\begin{array}{c}\text { (a) High } \\
\text { humidity }\end{array}$ & $\begin{array}{c}\text { (b) Low } \\
\text { humidity }\end{array}$ & $\begin{array}{c}\text { (c) High } \\
\text { humidity }\end{array}$ \\
\hline $\begin{array}{c}\text { Mean adhesive } \\
\text { force } \mu \mathrm{N} \\
\pm \text { S.D. }\end{array}$ & $\begin{array}{c}5.2 \\
\pm 3.2\end{array}$ & $\begin{array}{c}7.3 \\
\pm 4.3\end{array}$ & $\begin{array}{c}4.6 \\
\pm 3.0\end{array}$ \\
\hline $\begin{array}{c}\text { Number of } \\
\text { samples }\end{array}$ & 11 & 24 & 12
\end{tabular}

*Low humidity: 20 - 30\%R.H; High humidity: 70 $80 \%$ R.H.

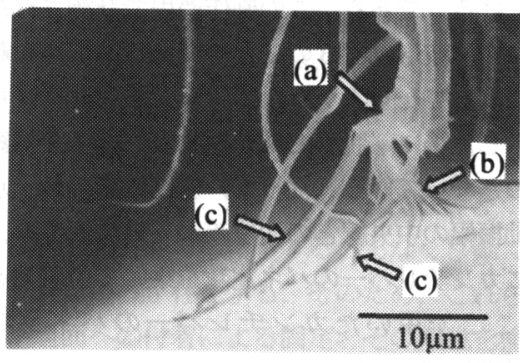

Fig.5 Tip of the left second leg of a spider mite: (a) a tarsus, (b) empodiums and (c) tenent hairs.

ら観察したときの脚先部を図 6 に示す。図 5 およひ図 6 (4)によると, 三対の爪間体(b)を間にしてその両側に 粘毛(c)が一対ずつ存在し，爪間体を体側（内側），粘 毛を外側に位置する状態で接地している. 爪間体と粘 毛の付け根は $90^{\circ}$ 近くの角度を持って連結し, 連結部 と跗節先端(a)は関節を構成している. また, 爪間体 や粘毛は跗節の太さに比べて細い。このような脚先の 

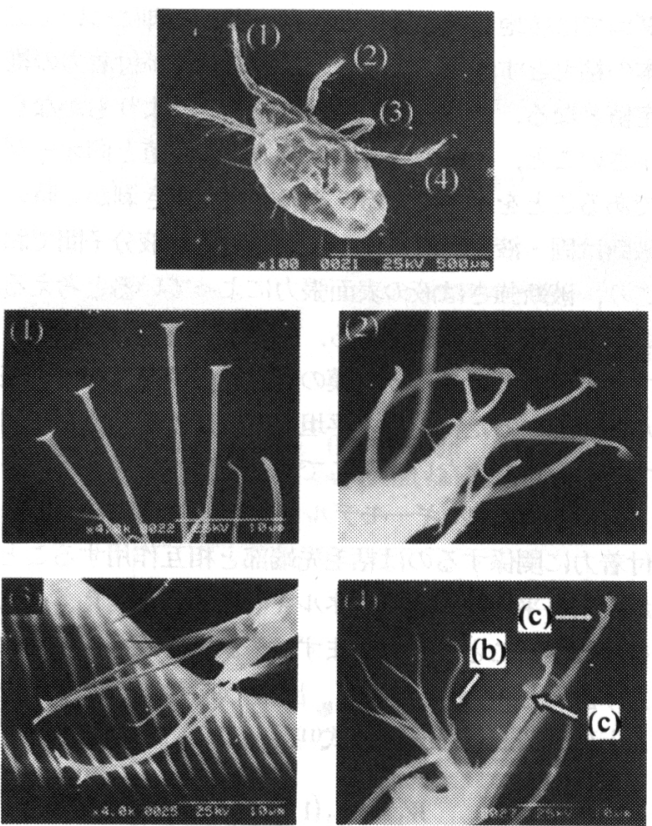

Fig.6 Tenent hairs of four legs of a spider mite.

特徵は位置関係が異なる四対のどの脚でも同様であっ た. 従って,バランスよく開いた爪間体と粘毛の双方 によって体を支え，付着は先に広がり部を持つ粘毛の 先端部が担っているものと推察される. 図6において 粘毛に着目すると, 粘毛の軸部の太さは $0.5 \mu \mathrm{m}$ 程度, 広がり部の大きさは $2 \mu \mathrm{m}$ 程度である. 広がり形状は, 扁平なもの (1), 凸なもの(2), 凹なもの(3)など様々で, 中には, 一つの脚で種々のタイプの混在しているもの (4)もある. 数多くのダニについて同様な観察を行な ったところ, 前脚では扁平形状, 後脚では爪間体の方 に凸形状を呈するものが比較的多く見られたが，そう でない場合も多々あり，先端のひろがり形状と脚位置 との間には定まった関倸はみられなかった，粘毛先端 の種々の広がり形状のうち凹形状に着目して拡大観測 した一例を図 7 に示す．先端は開きかけの朝顔の花状 になっている.これに平坦面を軸方向に強く押し付け れば扁平形状が，斜めに弱く押し付ければ凸形状が形 成可能であることから，図 7 のようなものが元の形で, 接地状況により種々の形に変形するものと思われる.

4.2 付首時の脚の功作 ガラス面上でのダ二脚 先の動作をガラスの裏面から光学顕微鏡で観察し, ビ デオに記録した．付着力測定と同様な操作でガラス面 に付着させたダニを引き剥がす場合では, ダニは面か ら離脱した脚を激しくばたつかせていることが特徴的 である，その一例を，脚をばたつかせた状態および第

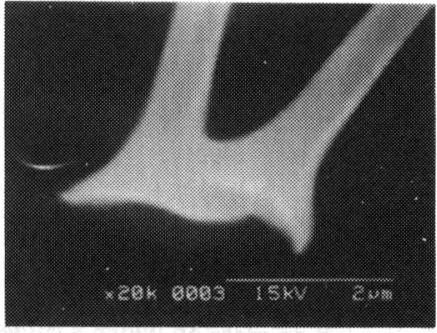

Fig.7 Tips of tenent hairs with a typical shape.
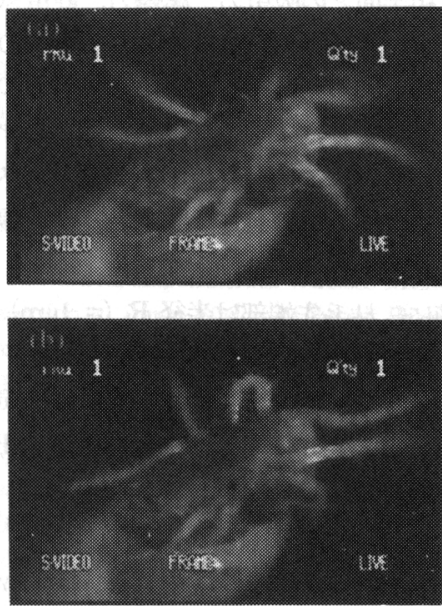

Fig. 8 A spider mite fluttering its legs on glass when being drowned off; all legs are fluttering in (a) and the second leg again adheres to the glass in (b).

二脚が再付着した状態の図 8 (a)，(b)で示す．ばたつ き動作は脚を体の遠い方から近くに引き付けるように 曲げることであり，一秒間に五回程度の頻度でその動 作を行なっている. その過程で再付着が生じるが, そ の位置は脚を引き付けた時の体に近い位置である.こ れに対して，歩行時においては，脚を体から比較的遠 い方に伸ばした位置で接地している.

また, 以上とは別に, 数多くのダニを小さな容器に 入れ，上部をスライドガラスで蓋をして放置し，重力 に逆らってガラス面に付着し，逆さ歩行したダニの残 した痕跡を調べた. 図 9 に位相差䡛微鏡による観測の 一例を示寸. 大きさが $1 \mu \mathrm{m}$ 程度の点状の痕跡が幾つ か認められる. それらは大きさが同程度である粘毛先 端の広がり部に対応するもので，その部から分泌液が 出る，あるいは，その部は剥離しや寸い状態にあるも のと思われる.

4.3 付㒸モテル 平滑面に付着するヤモリ(5), コ ガネムシ(6)，八エ(カ)よ゙の付着モデルについて, 脚先 


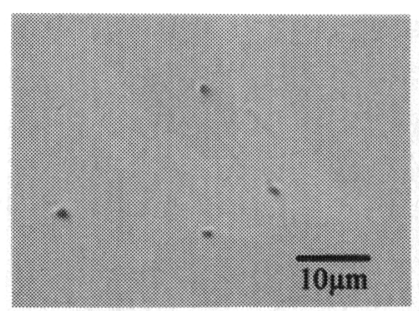

Fig. 9 Traces left on glass on which a spider mite hung and walked.

の付着部と相手面との吸引力, 摩擦力, 静電気力, 水 蒸気や分泌液の表面張力 (液架橋メニスカス力), 分 子間力によるものが挙げられている. 付着力の測定值 やそれぞれのモデルに基づく計算值などからヤモリで は分子間力が, 八エでは分泌液の液架橋メニスカス力 が主たるものであるとされている. 八ダニの場合につ いてもそれぞれのモデルを検討する.

今, 単純に, 粘毛先端部は半径 $\mathrm{R}(=1 \mu \mathrm{m})$ の円板 で相手面と密着や対向しているものとする.

(a) 吸引モデル : 対向部とそれ以外には一気圧の圧 力差 $\mathrm{P}(=0.1 \mathrm{MPa})$ がある. すなわち付着力 $\mathrm{F}_{\mathrm{s}}$ は,

$$
F_{s}=\pi R^{2} P \approx 0.3 \mu \mathrm{N}
$$

（b）液架橋メニスカスカモデル : 表面張力 $\gamma$ の液が 距離 $\mathrm{h}$ を隔てた対向部全域に架橋し, 半径 $\mathrm{R}_{\mathrm{m}}$ (= 0.5h）と R のメニスカスを形成している. また, 液 内外の圧力差 $\mathrm{P}$ はラプラスの式に従う。このときの 付着力 $\mathrm{F}_{\mathrm{m}}$ は( $^{(8)}$,

$$
F_{m}=\pi R^{2} \gamma\left(\frac{1}{R_{m}}-\frac{1}{R}\right)
$$

（c）分子間力モデル：対向面がわずかな距離 D を隔 ててほぼ密着し，両面間にはファンデルワールスカが 働いている. 寸なわち, 付着力 $F_{i}$ は, Hamaker 定数

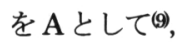

$$
F_{i}=\frac{A R^{2}}{6 D^{3}}
$$

結果は, 分泌液によるメニスカスカ $\mathrm{F}_{\mathrm{m}}$ は, 表面張 力を八工の場合と同様に $\gamma=30 \mathrm{mN} / \mathrm{m}$ とし, 液厚さ $2 \mathrm{R}_{\mathrm{m}}$ を表 1 の金スパッタ膜の表面粗さ $14 \mathrm{~nm}$ より大き いとして, $\mathrm{F}_{\mathrm{m}}=10 \mu \mathrm{N}\left(\mathrm{R}_{\mathrm{m}}=10 \mathrm{~nm}\right.$ のとき) や $2 \mu \mathrm{N}$ $\left(\mathrm{R}_{\mathrm{m}}=50 \mathrm{~mm}\right.$ のとき) を得る. また, 分子間力による $\mathrm{F}_{\mathrm{i}}$ は，固体と液体の双方に対寸る典型的な值 $\mathrm{A}=10^{-19}$

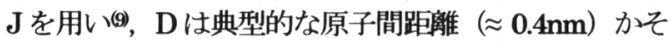
れよりも大きいとして(10), $\mathrm{F}_{\mathrm{i}}=260 \mu \mathrm{N}(\mathrm{D}=0.4 \mathrm{~nm} の$ とき) や $33 \mu \mathrm{N}$ （D=0.8nm のとき）を得る. 一匹の
ダニでは接地しているのは四本の脚，一脚について二 本の粘毛とすれば, 上で求めた力の八倍が付着力の推 定値となる.これらの結果は, $\mathbf{F}_{\mathbf{m}}$ は $\mathbf{F}_{\mathbf{i}}$ よりもかなり 小さいこと, 八倍の $\mathrm{F}_{\mathrm{m}}$ は付着力の測定值と同オーダ であることを示している. そのため，引き剥がし時の 破断は固・液の界面に比べて弱い付着の液分子間でお こり, 破断強さは液の表面張力によっていると考える のが妥当のように思われる. しかし，このことによっ て, ガラスと金スパッタ膜の測定値の間に 1.5 倍の差 があるといった付着力の平坦面材質による差異を説明 寸ることはできない. そこで次のモデルを考える.

（d）付着エネルギーモデル：平坦面材質に注目し, 付着力に関係するのは粘毛先端部之相互作用すること が出来る平坦面の表面エネルギーであると考え, それ を評価することとした，まずは，試験平坦面に表面張 カ $\gamma_{2}$ が既知の液を滴下し, 出来た液滴の接触角 $\theta$ を もとに, Young-Dupréの式(11),

$$
W_{12}=\gamma_{2}(1+\cos \theta)
$$

から面と液の付着エネルギー $\mathrm{W}_{12}$ を求めることとした 試験液として, 極性の高い結合を持たず表面張力が主 として分散力成分によるアクリル系の溶液 (Norland 社 NOA65, $\gamma=36.4 \mathrm{mN} / \mathrm{m}$, 粘度 $1200 \mathrm{cps}$ ）を用いた 場合に接触角 $\theta$ は図 10 のごとく得られた.

分散力のみが相互作用に寄与するときには $\gamma \mathrm{d}$ を表 面張力の分散力成分として,

$$
W_{12} \approx 2 \sqrt{\gamma_{1}^{d} \gamma_{2}^{d}}
$$

である(11. 今, 粘毛先端部も分散力成分からなるとする と, 平坦面と粘毛先端部の付着エネルギー $\mathbf{W}_{13}$ は, ガラ スを基準とした比で表すと次のごとくである.

$$
\begin{aligned}
& W_{13} / W_{13 \text { (glass) }} \\
& \approx 2 \sqrt{{\gamma_{1}^{d} \gamma_{3}^{d}}^{d}} / 2 \sqrt{\gamma_{1(\text { glass })}{ }^{d} \gamma_{3}^{d}} \\
& =2{\sqrt{\gamma_{1}^{d} \gamma_{2}^{d}}}^{d} / 2 \sqrt{\gamma_{1(\text { glass })}{ }^{d} \gamma_{2}{ }^{d}} \\
& \approx W_{12} / W_{12 \text { (glass) }}
\end{aligned}
$$

同様に，測定されたダニの付着力もガラスを基準と した比で表し, 両者の関倸を調べた. 結果は図 11 の ごとくであり，比であらわしたダニの付着力と分散力 相互作用による平坦面付着エネルギーとの間には高い 相関（相関係数 0.98）が認められた.

以上を総合すると次のように考えられる. 付着力は 平坦面との界面, 界面から粘毛先端部（あるとすれば 分必液もこの部に含まれる）にかけての部分のうち弱 


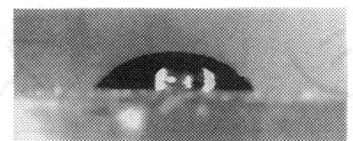

(a) Glass $\theta=45^{\circ}$

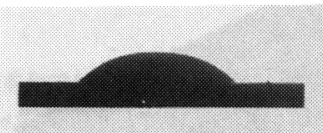

(c) Silicon $\theta=38^{\circ}$

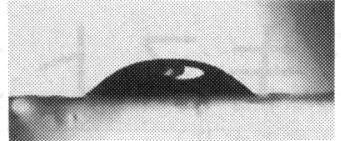

(b) $\operatorname{Mica} \theta=41^{\circ}$

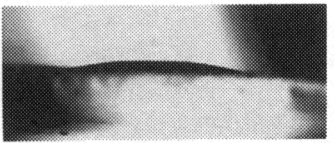

(d) Gold film $\theta=11^{\circ}$
Fig. 10 Contact angles $\theta$ between a droplet of acrylic solution and a flat surface.

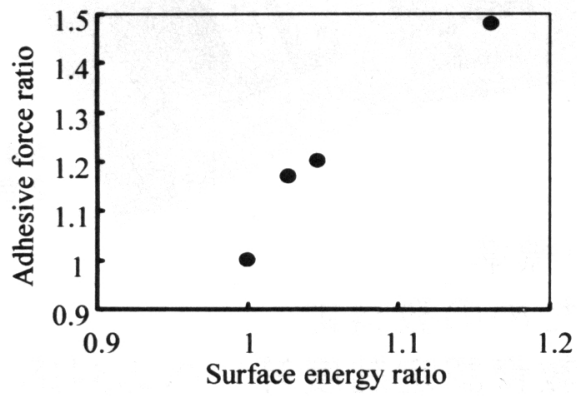

Fig. 11 Relationship between adhesive force and surface energy, each normalized by its counterpart for glass.

い方の特性により定まるものであるが，表面エネルギ 一の分散力成分の值が大きい平坦面では大きな付着力 が, 分散力成分の值が小さい水蒸気膜の存在によって 付着力は小さくなるなど分散相互作用に基づく界面の 特性に強く支配されている。 そして, その界面では, 粘毛と平坦面の間で相互作用を示す真の接触域は見か けの面積のうち僅かであると見られ，その域を増すた めに相手に倣って変形しやすい粘毛の構造と強い押し 付けを与える脚先の動作を伴っている. また, 粘毛先 端部の吸引力は付着に対する値としては小さいが, 粘 着性物質を先端部に吸い出寸役目を果たす可能性があ る.

\section{5. 䊅言}

ナミハダニの平坦面に対する付着力を平坦面の材質 や表面粗さ, 測定時の湿度を変えて測定し, また, 付 着の機構をダ二脚先の構造, 脚の動作, 付着モデルな どから検討し, 以下の結果を得た。
1）ナミハダニの付着力は，平滑ガラス面上では $8.2 \mu \mathrm{N}$ (体重の 37 倍) , 金スパッタ膜上では $12.1 \mu \mathrm{N}$ (体重の 54 倍) であるなど平坦面材質に よって変化し, 平坦面の表面エネルギーの分散力 成分の高い材料ほど大きい.

2) ナミハダニの付着力は平坦面の表面粗さが大きい 場合や相対湿度が高い状態では低下する.

3）平坦面との付着は, 粘毛先端にある $2 \mu \mathrm{m}$ 程度の大 きさの拡がり部が担っており, 開きかけの朝顔の 花形状は, 相手面に倣って押し付けるのに適して いる.

4）付着力の大きさを決定づけているのは粘毛先端拡 がり部と平坦面の界面における分散相互作用に基 づく付着エネルギーであると推察される.

\section{文䒜}

(1) N. Kawahara, Experimental Wireless Micromachine for Inspection on inner Surface of Tubes, Proceedings of the Sixth International Micromachine Symposium, (2000), 141-148.

(2) M. Takeda, Experimental Chain-type Micromachine for Inspection on Outer Surface of Tubes, Proceedings of the Sixth Intemational Micromachine Symposium, (2000), 149-153

（3）水谷勝己・江頭 快・東海 正, ダ二の微小步行機械 としての性能評価, 精密工学会秋季大会学術講演会講 演論文集，（2001），464-464.

（4）江原昭三・真梶徳純，植物ダ二学，（1996），2-3, 全国農村教育協会.

(5) K. Autumn, Y. A. Liang, S. T. Hsien, W. Zesch, W. P. Chan, T.W. Kenny, R. Fearing, and R. J Full, Adhesive forre of a single gecko foothair, Nature, 405-8 (2000), 681685.

(6) N. E. Stork, Experimental Analysis of Adhesion of Chrysolina (Chrysomelidate: Coleoptera) on a Variety of Surfaces, J. Exp. Bio, 88 (1980), 91-107.

(7) G. Walker, A. B. Yule and J. Ratcliffe, The adhesive organ of the Blowfly, Calliphora vomitoria a functional approach (Diptera: Calliphoridae), J. Zool Lond, A-205 (1985), 297307.

（8）例えば，小野 周，表面張力，（1994），14-16，共 立出版

（9） J. N. イスラエルアチヴィリ（近藤 保／大島広行 訳）, 分子間力と表面力, (2000)，172-204，朝倉 書店.

（10）同上, （2000）172-174, 朝倉書店.

（11）同上, （2000）308-311, 朝倉書店. 